\section{IAC Sintonia: new carioca common bean cultivar}

\author{
Alisson Fernando Chiorato ${ }^{1 *}$, Sérgio Augusto Morais Carbonell ${ }^{1}$, \\ João Guilherme Ribeiro Gonçalves ${ }^{1}$, Daiana Alves da Silva ${ }^{1}$, \\ Luciana Lasry Benchimol-Reis ${ }^{2}$, Cassia Regina Limonta \\ Carvalho², Vera Lúcia Nishijima Paes de Barros ${ }^{3}$, Rogério Soares \\ de Freitas ${ }^{4}$, Marcelo Ticelli ${ }^{5}$, Paulo Boller Gallo ${ }^{6}$ and Neli Cristina \\ Belmiro dos Santos ${ }^{7}$
}

\begin{abstract}
IAC Sintonia, new common bean cultivar, was developed to incorporate moderate resistance to the main pathogens Fusarium oxysporum and Colletotrichum lindemuthianum allied to great grain yield observed, 5,750.00 $\mathrm{kg} \mathrm{ha}^{-1}$. IAC Sintonia has semi-upright architecture and indeterminate growth habit (Type II), cycle is around 90 days and, 1000 seed weight of 280 grams.
\end{abstract}

Key words: Phaseolus vulgaris L., new cultivar, carioca type, Fusarium oxysporum, Colletotrichum lindemuthianum.

\section{INTRODUCTION}

Phaseolus vulgaris (common bean, dry edible bean, field bean), hereinafter bean, is a legume that is prominent in the diet on several continents and is an important source of protein, phosphorus, iron, vitamin B1, and fiber. It is of great socioeconomic importance and its cultivation generates jobs and income throughout the year. In the state of São Paulo, Brazil, growing and harvest of bean are concentrated in three crop seasons: the wet, dry, and winter season. According to the crop surveys, production in the state of São Paulo was estimated at 265.8 thousand metric tons in an area of 107.6 thousand hectares, with average yield of 2,470 $\mathrm{kg} \mathrm{ha}^{-1}$. Brazilian production as a whole is estimated at 3,285.6 thousand metric tons in an area of 3,078 thousand hectares, with average yield of 1,067 $\mathrm{kg} \mathrm{ha}^{-1}$ (CONAB 2017).

There was an increase in average grain yield compared to the previous harvest, and this may be attributed to some crop management factors. However, plant breeding with the insertion of genetic resistance to diseases (Carbonell et al. 2010, Henrique et al. 2015, Azevedo et al. 2015, Melo et al. 2017) and an increase in the yield capacity of cultivars through various selection cycles have contributed to increase production potential, together with high quality of the grains.

Barili et al. (2015), reinforcing the importance of developing new cultivars, investigated the relationship between an increase in grain yield and the adaptability and phenotypic stability parameters in carioca (beige with brown stripe seed coat) bean cultivars recommended by several Brazilian institutions in the last 40 years, thus confirming that the effective increase in grain yield is the result of recommendation of new cultivars over the decades and that the cultivars recently recommended combine high yields, wide adaptability, and high predictability.
Crop Breeding and Applied Biotechnology 18: 338-342, 2018 Brazilian Society of Plant Breeding. Printed in Brazil http://dx.doi.org/10.1590/1984$70332018 v 18 n 3 c 51$

\section{*Corresponding author: E-mail: afchiorato@iac.sp.gov.br}

Received: 22 August 2017 Accepted: 14 November 2017

${ }^{1}$ Instituto Agronômico de Campinas, Centro de Análises e Pesquisa Tecnológica do Agronegócio dos Grãos e Fibras, 13020-902, Campinas, SP, Brazil ${ }^{2}$ Instituto Agronômico de Campinas, Centro de Pesquisa e Desenvolvimento de Recursos Genéticos Vegetais, 13.020-902, Campinas, SP, Brazil

${ }^{3}$ Agência Paulista de Tecnologia dos Negócios, Pólo Regional de Desenvolvimento Tecnológico do Agronegócio, 18.300-970, Sudoeste Paulista, Capão Bonito, SP, Brazil

${ }^{4}$ Instituto Agronômico - IAC - Centro APTA de Seringueira e Sistemas Agroflorestais, Zona rural, 15.500-000, Votuporanga, SP, Brazil ${ }^{5}$ Agência Paulista de Tecnologia dos Negócios Sudoeste Paulista, Pólo Regional de Desenvolvimento Tecnológico do Agronegócio, km 38, 18.300-970, Tatuí, SP, Brazil ${ }^{6}$ Agência Paulista de Tecnologia dos Negócios Nordeste Paulista, Pólo Regional de Desenvolvimento Tecnológico do Agronegócio, 13.730-980, Mococa, SP, Brazil ${ }^{7}$ Agência Paulista de Tecnologia dos Negócios Extremo Oeste, Pólo Regional de Desenvolvimento Tecnológico do Agronegócio, 16.900970, Andradina, SP, Brazil 
In this respect, studies in bean breeding of the Instituto Agronômico de Campinas, Brazil, at the Centro de Pesquisa Tecnológica dos Agronegócios dos Grãos e Fibras, emphasize not only high yield, adaptability, and production stability, but also the need to obtain plants with resistance to the main bean diseases, such as anthracnose and Fusarium wilt. In relation to Fusarium wilt, lack of chemical control makes the insertion of genetic resistance an important strategy for growing bean in infected areas because this disease attacks the root system, leading to necrosis of the xylem and risk of total crop loss.

The aim of the present study was to present data on the bean inbred line FAP-F3RC2-2 in the Valor de Cultivo e Uso -VCU (Value for Cultivation and Use) trials in the state of São Paulo in the three growing seasons, resulting in registration of the bean cultivar IAC Sintonia.

\section{GENETIC ORIGIN AND DEVELOPMENT}

The cultivar IAC Sintonia, inbred line $\mathrm{FAP}-\mathrm{F}_{3} \mathrm{RC}-2$, was developed by the bean breeding program of IAC to incorporate moderate resistance to the pathogen Fusarium oxysporum in the IAC Alvorada cultivar. Thus, in 2009 a single cross was made between cultivars with the carioca seed coat, IAC Alvorada x Pérola, which generated $157 F_{1}$ seeds. From these $F_{1}$ seeds, backcrosses were made using the IAC Alvorada cultivar as a recurrent parent because of its excellent grain quality. From the first backcross $\left(F_{1} R C_{1}\right)$, 31 seeds were obtained. In 2010, these $31 F_{1} R C_{1}$ seeds were sown to carry out a new backcross with the IAC Alvorada cultivar, and 135 seeds of the $\mathrm{F}_{1} \mathrm{RC}$ generation were obtained. As of this generation, inoculation with the pathogen Fusarium oxysporum began for the purpose of selecting only resistant seedlings for advancing generations.

With the inoculations made, 126 seedlings were obtained, and the proportion of resistant/susceptible plants for the backcross $\mathrm{F}_{1} \mathrm{RC}_{2}$ was 1:3.5, respectively, i.e., 28 seedlings were resistant and 98 were susceptible. The inoculum of $F$. oxysporum was adjusted to concentrations of $1 \times 10^{6}$ conidia $\mathrm{mL}^{-1}$ (macro and microconidia), with a mixture in the same concentration of races 1 (American) and 2 (Brazilian). The inoculation was performed by cutting the roots in one third of the length, which were immersed in the inoculum during 15 minutes; then the roots were transplanted into pots with $500 \mathrm{~g}$ of substrate (organic compost and soil in proportion 1:1) packed in a greenhouse. The evaluation of symptoms was performed 30 days after inoculation, according to the grading scale developed by Nascimento et al. (1995), where 0 indicates the absence of symptoms (resistant), and 4 plants with dwarfism, wilted or dead (susceptible). Intermediate scores were considered to be moderately resistant.

In 2011, seeds of the $\mathrm{F}_{2} \mathrm{RC}_{2}$ generation were inoculated for the anthracnose pathogen (Colletotrichum lindemuthianum) through a mixture of the physiological races 65,81 , and 95 . The seeds were sown in plastic trays, which contained sterilized vermiculite and, the inoculation was carried out by spraying the inoculum $\left(1 \times 10^{-6}\right.$ conidia $\left.\mathrm{mL}^{-1}\right)$ to the aerial surface of the plants in V2 development stage. After inoculation, the plants were transferred to a controlled room with temperature, humidity and photoperiod respectively of $20^{\circ} \mathrm{C}, 95 \%$ relative humidity and 12 hours during 48 hours, thence then the humidity control has been shut down, and the plants remained for another seven days at 20 ${ }^{\circ} \mathrm{C}$ for evaluation.

After inoculation, 100 resistant seedlings were selected, which were transplanted in pots in a greenhouse. Of the 100 seedlings transplanted to pots, only 76 produced seeds, and from this production, the $\mathrm{F}_{3} \mathrm{RC}_{2}$ generation was obtained. In 2012, plants of the $\mathrm{F}_{3} \mathrm{RC}_{2}$ generation were sown in a field infected with Fusarium oxysporum, and the 250 plants selected were carefully identified, with selection based on resistance to Fusarium oxysporum, upright plant architecture, tolerance to bacteriosis caused by Xanthomonas axonopodis (a naturally occurring, non-inoculated disease), first pod height, and plant lodging. These 250 plants selected in the field were also evaluated in regard to grain quality, considering sieve yield, light grain color, and tolerance to darkening. A total of 49 plants were selected to form the $\mathrm{F}_{4} \mathrm{RC}_{2}$ generation. Because the plants had been selected in the $\mathrm{F}_{3} \mathrm{RC}_{2}$ generation, the 49 genotypes were sequentially denominated as $\mathrm{F}_{3} \mathrm{RC}_{2}-1 \ldots$ to $\mathrm{F}_{3} \mathrm{RC}_{2}-49$.

The agronomic potential of each one of the 49 selected lines were evaluated in the 2013 dry season at the Pólo Regional de Desenvolvimento Tecnológico de Capão Bonito (Capão Bonito Regional Technological Development Center), which is a research center connected with the Agência Paulista de Tecnologia dos Agronegócios - APTA (São Paulo Agribusiness Technology Agency). As of the $\mathrm{F}_{4} \mathrm{RC}_{2}$ generation, each line was considered a parent line, and thus, selections 
among the lines began. From the 49 genotypes evaluated, 15 lines with better yield performance were selected, and a new experiment was set up in the 2013 winter season at the Pólo Regional de Desenvolvimento Tecnológico de Colina (Colina Regional Technological Development Center), also connected with the APTA. In this experiment, only one line was selected, F3RC2-2. The same line was denominated by the abbreviation $F A P F_{3} R C_{2}-2$ in which:

F: designates resistance to Fusarium oxysporum;

A: designates resistance to anthracnose;

$\mathrm{P}$ : designates upright plant architecture;

$\mathrm{F}_{3} \mathrm{RC}_{2}-2$ : generation in which selection of the line occurred, and the sequence was established to differentiate it from the other lines.

Furthermore, in 2013, the line FAP $F_{3} R_{2}-2$ was part of the VCU trials in the state of São Paulo and was evaluated in 14 environments and six crop seasons. In the 2013 rainy season in Capão Bonito and Mococa, it had an average yield of 3,602 kg ha-1; in the 2014 dry season in Ribeirão Preto and Mococa, it had an average yield of 2,550 kg ha-1; in the 2014 winter season in Tatui and Votuporanga, it had an average yield of 3,635 kg ha-1; in the 2014 rainy season, evaluated in the Mococa, Capão Bonito, and Itararé environments, it had an average yield of 3,505 kg ha-1; in the 2015 dry season, with sowing in Mococa, Capão Bonito, and Itararé, it obtained an average yield of 1,711 kg ha-1; and in the 2015 winter season, evaluated in the environments of Votuporanga and Adamantina, it had an average yield of 4,247 $\mathrm{kg} \mathrm{ha}^{-1}$. Considering the mean yield of all the trials listed above, the $\mathrm{FAP} \mathrm{F}_{3} \mathrm{RC}-2$ line had an average yield of $3,174 \mathrm{~kg}$ $\mathrm{ha}^{-1}$, which is superior to the standard controls IAC Milênio, with average yield of 2,701 $\mathrm{kg} \mathrm{ha}^{-1}$, and IPR Tangará, with average yield of $2,780 \mathrm{~kg} \mathrm{ha}^{-1}$.

\section{YIELD CAPACITY}

From performance analysis of the IAC Sintonia cultivar in the 14 environments evaluated in VCU trials, it could be verified that the maximum yield of the cultivar was $5,750 \mathrm{~kg} \mathrm{ha}^{-1}$, obtained in the Votuporanga environment in the 2015 winter season. The average yield for the three growing seasons, rainy ( 5 environments), dry ( 5 environments), and winter (4 environments), were 3,533 $\mathrm{kg} \mathrm{ha}^{-1}, 2,047 \mathrm{~kg} \mathrm{ha}^{-1}$, and 3,941 kg ha-1, respectively. These average yields were superior to the two control cultivars (IAC Milênio and IPR Tangará) for the three seasons analyzed (Table 1). This yield superiority also occurred for the overall average yield, exhibiting yield increases of $473 \mathrm{~kg} \mathrm{ha}^{-1}$ and $394 \mathrm{~kg} \mathrm{ha}^{-1}$ in relation to the yields shown by the two control cultivars evaluated, respectively. In spite of the higher average yields shown by IAC Sintonia, a significant difference among the controls was not observed. Nevertheless, the presence of resistance to anthracnose and moderate genetic resistance to Fusarium wilt, together with the quality of grains originating from the parent IAC Alvorada, highlight the potential of the IAC Sintonia cultivar for both growing and for the commercial market.

Table 1. Mean performance of grain yield $\left(\mathrm{kg} \mathrm{ha}^{-1}\right)$ by Dunett test $(\mathrm{p}>0.05)$ in relation to the best standard cultivar in regard to the three bean crop seasons cultivation, as well as in relation to the overall mean of 25 bean lines and cultivars, evaluated in 14 environments of the state of São Paulo in the VCU trials of the. 2013, 2014 and 2015 years and, the percentage in relation of the two witnesses average (C\%)

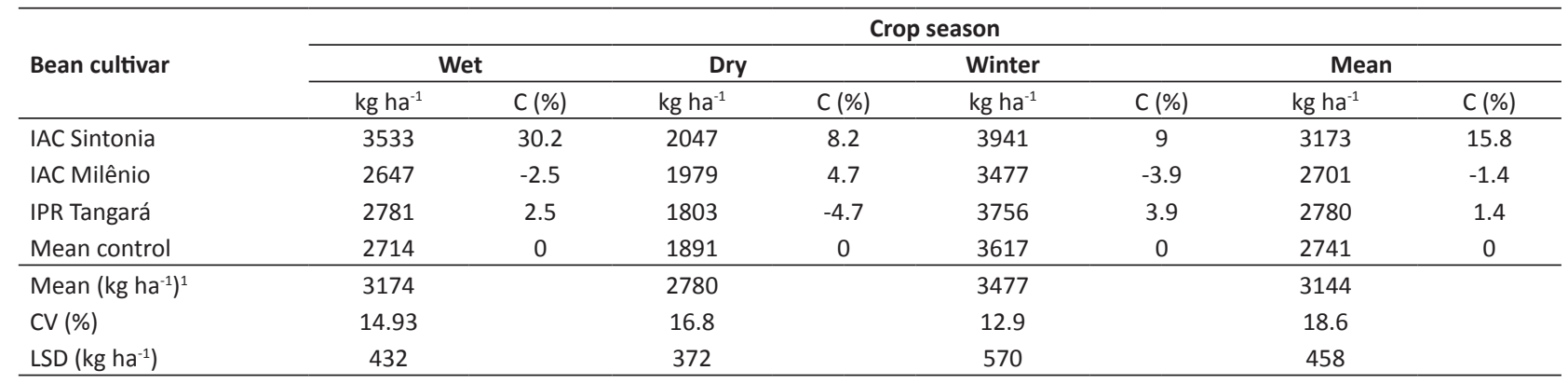

${ }^{1}$ Experimental mean containing 25 bean lines and cultivars with a coefficient of variation less than $25 \%$; 
IAC Sintonia: new carioca common bean cultivar

Table 2. Technological and nutritional quality: Mean performance by Dunett test $(p>0.05)$ of cooking time by the Mattson Cooker and protein content (\%) in bean seeds cultivated in the 2009/2010/2011 biennium in 14 environments in the state of São Paulo in VCU trials.

\begin{tabular}{lcccccc}
\hline \multirow{2}{*}{ Crop season } & \multicolumn{2}{c}{ IAC Sintonia } & \multicolumn{2}{c}{ IAC Milênio } & \multicolumn{2}{c}{ IPR Tangará } \\
\cline { 2 - 7 } & $\begin{array}{c}\text { Cooking time } \\
(\mathrm{min})\end{array}$ & $\begin{array}{c}\text { Protein content } \\
(\%)\end{array}$ & $\begin{array}{c}\text { Cooking time } \\
(\mathrm{min})\end{array}$ & $\begin{array}{c}\text { Protein content } \\
(\%)\end{array}$ & $\begin{array}{c}\text { Cooking time } \\
(\text { min) }\end{array}$ & $\begin{array}{c}\text { Protein content } \\
(\%)\end{array}$ \\
\hline Wet & 40.31 & 19.5 & 36.47 & 19.50 & 37.64 & 19.50 \\
Dry & 36.92 & 20.5 & 34.34 & 21.00 & 28.18 & 19.50 \\
Winter & 32.59 & 20.5 & 41.38 & 19.50 & 33.74 & 19.00 \\
Mean & 36.61 & 20.17 & 37.40 & 20.00 & 33.19 \\
\hline
\end{tabular}

Table 3. Average performance of the cultivar IAC Sintonia and of the witnesses IAC Milênio and IPR Tangará for main characteristics as: Cycle (C), Sieve yield (SY), mass of thousand grain (MTG), Antracnose reaction (AR), Fusarium wilt reaction (FWR), Angular leaf spot reaction (ALSR) and Bacterial blight reaction (BBR)

\begin{tabular}{lcccccc}
\hline Cultivar & $\begin{array}{c}\text { C } \\
\text { (days) }\end{array}$ & $\begin{array}{c}\text { SY (12) } \\
(\%)\end{array}$ & $\begin{array}{c}\text { MTG } \\
\text { (g) }\end{array}$ & AR & FWR & $\begin{array}{c}\text { ALSR } \\
\text { (Mixture of isolates) }\end{array}$ \\
\hline IAC Sintonia & 90 & 92 & 290 & MR & MR & MR \\
IAC Milênio & 92 & 88 & 280 & MR & R & MR \\
IPR Tangará & 92 & 89 & 290 & S & R & MR \\
\hline
\end{tabular}

R: Resistant to the pathogen; MR: Moderately resistant to the pathogen; S: Susceptible to the pathogen.

\section{OTHER CHARACTERISTICS}

The IAC Sintonia cultivar has semi-upright architecture and indeterminate growth habit (Type II), with moderate resistance to Fusarium wilt (Fusarium oxysporum), 1000 seed weight of 280 grams, and carioca type seeds with light brown stripes. Its average cycle is 90 days from emergence to physiological maturity, in accordance with the environmental conditions in which it is grown. The cultivar exhibits tolerance to anthracnose (Colletotrichum lindemuthianum) as found by inoculations under controlled conditions in the laboratory and later observation in the production field throughout the segregating generations.

No significant difference was observed among the genotypes for average cooking time (minutes) and protein content (\%) accessed respectively by methodologies of Mattson cooker (Proctor and Watts 1987) and microKjeldahl crude protein analyzes (AOAC 1980, Bataglia et al. 1983). However, for the winter season (5 environments), the IAC Sintonia cultivar had a lower average for cooking time (32.59 $\mathrm{min})$, as well as a higher average for protein content (20.5\%), in relation to the two controls (IAC Milênio and IPR Tangará) (Table 2).

The main relevant characteristics of the cultivar IAC Sintonia as well as in comparison to the witnesses are listed at Table 3.

\section{TECHNICAL RECOMMENDATION AND SEED PRODUCTION}

Considering the grain yield obtained, tolerance to pathogens of anthracnose and to Fusarium oxysporum, and especially through exhibiting upright plant architecture, the cultivar IAC Sintonia is recommended for cultivation in the wet, dry, and winter crop seasons in the state of São Paulo, and can also be recommended for the wet and dry crop seasons in the states of Paraná, Santa Catarina, Rio Grande do Sul, and Mato Grosso do Sul.

A between-row spacing of $50 \mathrm{~cm}$ with 10 viable plants per linear meter is recommended, for a total of 220,000 plants per hectare.

\section{REFERENCES}

AOAC (1980) Official methods of analysis of the A.O.A.C. $13^{\text {th }}$ edn, Association of Official Analytical Chemists, US Government Printing Office, Washington D.C. (15.048).

Azevedo CVG, Ribeiro T, Silva DA, Carbonell SAM and Chiorato AF (2015)
Adaptabilidade, estabilidade e resistência a patógenos em genótipos de feijoeiro. Pesquisa Agropecuária Brasileira 50: 912-922.

Barili LD, Vale NM, Prado AL, Carneiro JES, Silva FF and Nascimento M (2015) Genotype-environment interaction in common bean cultivars with carioca grain cultivated in Brazil in the last 40 years. Crop 


\section{AF Chiorato et al.}

Breeding and Applied Biotechnology 15: 244-250.

Bataglia OC, Furlani AMC, Teixeira JPF, Furlani PR and Gallo JR (1983) Métodos de análise química de plantas. Instituto Agronômico, Campinas, 48p. (Boletim Técnico, 78).

Carbonell SAM, Chiorato AF, Carvalho CRL, Ramos Junior EU, Ito MK, Borges WLB, Ticelli M, Santos NCB and Gallo PB (2010) IAC Formoso: new carioca common bean cultivar. Crop Breeding and Applied Biotechnology 10: 374-376.

CONAB - Companhia Nacional de Abastecimento (2017) Available at: <http://www.conab.gov.br/OlalaCMS/uploads/ arquivos/17_04_17_17_20_55_boletim_graos_abr_2017.pdf>. Accessed on Aug 06, 2017

Henrique FH, Carbonell SAM, ITO MF, Gonçalves JGR, Sasseron GR and Chiorato AF (2015) Classification of physiological races of
Fusariumoxysporum f. sp. phaseoli in common bean. Bragantia 74: 84-92.

Melo LC, Pereira HS, Faria LC, Souza TLPO, Wendlan A, Díaz JLC, Carvalho HWL, Melo CLP, Costa AF, Magaldi MCS and Costa JGC (2017) BRS FC402: high-yielding common bean cultivar with carioca grain, resistance to anthracnose and fusarium wilt. Crop Breeding and Applied Biotechnology 17: 67-71.

Nascimento SRC, Kurozawa C and Maringoni AC (1995) Avaliação de raças fisiológicas de Fusarium oxysporum f. sp. phaseoli. Fitopatologia Brasileira 20: 214-217.

Proctor JR and Watts BM (1987) Development of a modified Mattson bean cooker procedure based on sensory panel cookability evaluation. Canadian Institute of Food Science and Technology Journal. Apple Hill 20: 9-14. 